\title{
The Use of Accounting System in the Nonprofit-Oriented Church Organizations of Nigeria
}

\author{
J.C.Ihemeje*, Geff Okereafor, Bashir M. Ogungbangbe \\ College of Management Sciences, Michael Okpara University of Agriculture, Umudike \\ "Email (corresponding author): jamesihemejejournals@gmail.com
}

\begin{abstract}
The objective of the study is to appraise accounting system in nonprofit organization. Both primary and secondary sources of data collection were used in generating relevant data for this study. The adoption of accounting system does enhance the accountability and transparency of financial records and activities of the Church. The attitude of senior officials of the Church towards accounting system is negative. The use of accounting system has a strong effect on the financial activities of the organization. The accounting system should be adopted by a nonprofit organization to enhance the accountability and transparency of financial records and activities of organizations. Senior officials of the organization should develop a positive attitude towards accounting system owing to its notable contribution to the growth and development of the organization.
\end{abstract}

Keywords: Accounting System, Non-profit Organization, Churches, Nigeria

\section{Introduction}

Most business organizations either profit driven or not, engage in decision making on a daily basis in order to keep the organization abreast with recent developments in the business environment they operate. Accounting system provides requisite financial information that enhances and improves the quality of decision made by non-profit organizations (Barth, 2001). Hence, it can safely be concluded that Accounting System is not an end in itself but a means to an end i.e. decision making to improve corporate performance and financial structure. Gone were the days when business organizations - profit oriented or not - were simply required to make a profit, survive and provide a fair return to investors' on their interest. Meyer (2007) opined that, modern business organizations find itself in the atmosphere of global uncertainties, cut-throat competition locally and internationally and unprecedented change in the economy. Hence, a great demand is often placed on the managers of these organizations to make pragmatic and informed decisions if the organization is to move forward as the success or otherwise of any organization is often a function of the sum of the decisions taken in the past (Minton, 1996). However, the quality of decisions taken by managers and other relevant personnel in the organization rests upon the substance and accuracy of information provided by accounting systems available to them.

An accounting system is one of the most effective decision-making tools of management, as it provides an orderly method of gathering and organizing information about the various business transactions so that it may be used as an aid to management in operating the business. Accounting information also help managers understand their tasks more clearly and reduce uncertainty before making their decisions (Chong, 2001). Nicoloau (2000) opined that accounting system produces detailed and comprehensible accounting information which are an invaluable basis for decision making. In recent times, it has tended to be a system of information that does not stop at limits of data and financial information, but also it include data and descriptive and quantitative information which is useful in decision making for users distinct with plurality and diversity. Such users include current and potential investors, lenders, suppliers, creditors, customers, governments and the public in addition to the administration, which is its responsibility to prepare the accounting programs and display it, such information must be capable of achieving the goal that it has been prepared for. Hence the role of Accounting Information System for effective decision making cannot be over emphasized. It is against this background that the researcher deemed it of pertinent concern to embark on a research 
exercise to appraise and provide relevant information on the impact of accounting system in non-profit oriented business organization.

\section{Conceptual Framework}

The commercial enterprises established with profit motive prepare trading, profit and loss account in order to ascertain the net financial result of their operations. Non-profit associations such as social and athletic club, societies, churches, voluntary association, hospital, benevolent and similar institutions do not prepare trading and profit and loss account because they are not established with profit in view. But notwithstanding their nonprofit posture, the need for accountability dictates that some form of accounting must be maintained. Demski (2003), viewed the non-profit organization as an organization purposely established not to embark on any motive but to render social and spiritual welfare to its members. Choe, (1996) sees the non-profit organization as a nonprofit oriented organization set up to provide welfare to its members.

The not-for-profit organization currently provides financial statement that differs in their form and content. For example most hospitals, made associations and membership organizations provide a statement of financial position and a statement of activities (or statement of revenues and expenses) that report their financial position and results of operations to the entity as a whole. In contrast, universities, museums, religious organizations, and certain other notfor-profit loose organizations often provide financial statements that report the financial position and changes in financial position of individual fund groups, but many do not report financial position and results of operation for the entity as a whole. Recently, some not-for-profit organizations have begun reporting cash flow information, but most do not. (Alsharayri, 2013). Further, voluntary health and welfare organizations generally provide a statement that reports expenses by functional classification and by natural classification, but most other not-for-profit organizations do not.

\subsection{Financial Statement/Account Maintained By Non-Profit Organization}

Certainly, proper accounting is essential for non-trading institutions. These concerns maintain, generally, a cash book and later they prepare a summary of cash transactions appearing in the cash book. This summary takes the form of an account known as receipts and payments account such concerns also prepare income and expenditure account'( which is more or less on the lines of profit and loss account) and the balance sheet.

The day-to-day accounting of non-profit organization consists of maintaining.

- Cash book for recording receipts and payments, and

- ledger for classification of transactions under proper heads.

Receipts and Payments Account :It is a summary of cash book for a given period, but the receipts and payments account shows the totals of cash transactions under different heads. All receipts, be it cheque or cash are entered on the debit (receipts side), all the receipts, be it cheque or cash are entered on the debit (receipts0 side (as in cash book) whereas all the payments (both by cheque or cash) are shown on the credit (payments) side. Following features of the receipts and payments account will help to identify its nature clearly.

It is a summary of cash book, like a cash book, receipts are shown on the debit side and payments on the credit side. Cash and bank items are merged in one column. That means receipts in cash as-well-as by cheque are entered in one column on debit and payments in cash as-well-as by cheque are entered it one column on credit side. Contra entries between cash and bank get eliminated. It is not a part of double entry book keeping. It is just a summary of cash book which is a part of double entry system. Just like cash book, it starts with the opening balance of cash and bank and closes with the closing balance of cash and bank. Both revenue and capital receipts and payments are recorded in this account. For example, an organization that is exclusively set up to carry on with the object of carrying out social service or promote \& organization of social activities, is a non-trading enterprise payment for rent and payment for building and machinery both are recorded on its payments side. Similarly, receipts on account of subscription and machinery are shown on the receipts side. Usually, it shows a debit balance which represents cash in hand and at bank. However, in the case of bank overdraft, which is larger than cash in hand, the account will show a credit balance. Receipts and payments account fails to disclose gain or loss made by the concern during the period because (a) it is prepared on actual receipt basis i.e. It records all receipts-irrespective of the period to which it relates (previous year, current year or future), (b) it also ignores the nature of the receipts and payments (whether capital or revenue. Accounting concept of gain or loss is based on 'accrual concept' which by its very nature 'receipts and payments 
account" not capable of considering. Therefore, fails to disclose gain or loss earned or suffered by the concern) during the period.

For example, this account ignores.

- Decrease or increase i.e. depreciation or appreciation in the value of assets;

- Increase or decrease in the value of stock;

- Provision for expenses incurred but payments not made-outstanding expenses

- Accounting for payment in advance for the services to be utilized in the next accounting period - prepaid expenses.

- It also fails to distinguish between;

- Capital and revenue payments-whether expenditure or purchase of an asset, and

- Business charge and appropriation - whether business expenditure or drawings

\section{Limitations of receipts and payments account}

Receipts and payments account suffers from following limitations:

- It does not show expenses and incomes on accrual basis.

- It does not show whether the club or society is able to meet its day-to-day expenses out of its incomes.

- It does not show expenses on account of depreciation of assets.

- It does not explain the details about many expenses and incomes. a explain such questions, treasurer of the club prepares 'Income and expenditure account' and balance sheet.

Income and expenditure account: Again in the view of Bernard, (1995) citing Landsman (2001) identified also income and expenditure account prepared by the non-profit organization. $\mathrm{N}$ this account is prepared by non-trading concerns who want to know if during the financial year their income has been more than their expenditure i.e. profit or vice versa (.i.e loss), Since the object of these concerns is not primarily to earn profit, therefore, they feel shy in giving it the name of profit and loss account. Because the word 'profit' is a taboo which any society 'looks down upon'. Of course, it discloses whether the concerned institution earned or lost. It is equivalent to and serves the purpose of 'profit and loss account'

It is prepared on "accrual basis" (not on receipt basis) meaning thereby that all incomes are be included which have been earned in the relevant period (whether actually received or not). Similarly, it includes all expenses incurred in the relevant period (whether actually paid or not). This account serves exactly the purpose which 'profit and loss account'serves in a trading concern. On the pattern of 'profit and loss account' income is shown on the credit side and expenditure on the debit side. It also distinguishes between 'capital \& revenue' item i.e. it does not take into consideration capital items \{both receipts and payment].it follows double entry principles faithfully (Chang 2001).

Balance Sheet: Boockholdt, (1999) pointed out that non-profit organization in order to determine their asset and liabilities maintain a balance sheet. The balance sheet of a non-trading concern is on usual lines, Liabilities on left-hand side and assets on right-hand side. In trading concerns, an excess of assets over liabilities is called 'capital fund'. The capital fund is built up out of surplus from income and expenditure account.

\subsection{Distinction between "receipts and payments account" and "Income and expenditure account"}

Meyer, (2007), highlights the difference that exist between the receipts and payment account and income and expenditure account maintained by non-profit making organization

Receipts and Payments Account: It is a real account

- It need not be accompanied by a balance sheet

- It is like a cash book

- Closing balance is carried forward to the next period

- Debit side is for receipts and credit side is for payments

- $\quad$ Closing balance represents cash in hand and at the bank.

- It includes both capital and revenue items. 
- It usually shows a debit balance.

- It ignores outstanding items.

- It ignores credit sales and purchases.

- It includes prepaid items.

- It begins with a balance.

- It includes items relating to past, present or future periods.

- It is not a part of double entry system

- It ignores non-cash items like depreciation, bad debts etc

Income and Expenditure Account: It is a nominal account

- Must be accompanied by a balance sheet

- It is like a profit and loss account

- Closing balances is merged into capital fund

- Debit side is for expenses and credit side for incomes

- Closing balance represents either surplus or deficiency

- It includes only revenue items

- It may show a debit or credit balance

- It records outstanding items.

- It records credit sales and purchases

- It excludes prepaid items

- It does not begin with a balance

- It includes items relating to current period only

- It is a part of double entry system

- It records non-cash items like depreciation, bad debts etc

\subsection{Peculiar sources of fund raising for Non-Trading Concern}

Ologunde, (2006), identified peculiar ways through which non-profit organization could raise and obtained fund and how such items are treated in the accounts kept by nonprofit organization. Among these sources of fund and its accounting, treatment include:

Legacy: It is the amount received by the concern as per the will of the 'donor'. it appears on the receipts side of receipts and payments account it should not be considered as income but should be treated as capital receipt i.e., credited to capital fund account (Quinn and Rohrbaugh, 2005)

Subscriptions: The members of the associations, as per rules, are generally required to make an annual subscription to enable to serve the purpose for which it was created. Sometimes may be church offers, harvest dues, etc. it appears on the receipts side of the receipts and payments credited to income credited. Care must be exercised to take credit for only those subscriptions which are relevant.

Life Membership Fees: Generally, the members are required to make the payment in a lump sum only once which enables them to become the members for the whole of the life. Life members are not required to pay the annual membership fees. As life membership fees' is a substitute for 'annual membership fees'. Therefore, it is desirable that life membership fees should be credited to a separate fund and fair proportion be credited to income in subsequent years. In the examination question, if there is no instruction as to what proportion be treated as income then whole of it should be treated as capital (Ologunde, 2006).

Entrance fees: Most times in the church the entrance fees may be in form of occasion the church is conducting. Such occasion may include church harvest, church harvest, church anniversary, etc. Something like pin-up may be organized to be sole the members as a source of raising fund. This is also found on the receipts side of receipts and payments account. There are arguments that it should be treated as capital receipt because every member only once (i.e) pays entrance fees. When enrolled as member. It should be credited to income. In their absence of the instructions anyone of the above treatment may be followed by students should append a note justifying their treatment (Rommey, 2003).

Sale of Periodicals, Bulletins etc.: As the bulletins, church magazines, and periodicals etc. are to be disposed to every member, the receipts on account of such sale should be treated as income, and therefore, to be credited to income and expenditure account.

Sale of Sports Material: Sale of sports material (used) is also a regular feature of the church. Sale proceeds should be treated as income, and therefore, to be credited to income and expenditure account. 
Honorarium: Persons may be invited to deliver lectures, seminar or sermon, he may be awarded an honor and out of his $b$ benevolent he may give the church some money. Any money, paid of such, is termed as honorarium and such honorarium represents income and not an expenditure and will be debited to income and expenditure account.

Special Fund: Legacies and donations may be received for specified purposes. As discussed above, these should be credited to special fund all expenses related to such fund are shown by way of deduction from the respective fund and not as expenditure in income and expenditure account.

Sale Of Old Asset: It is a non-recurring item. It cannot be taken to income and expenditure account. It leads to a reduction in the asset. Therefore, it is shown by way of deduction from the concerned asset. It is important to note that it is the "book value" that is to be deducted from the asset. Profit or loss in such a case is taken to income and expenditure account. Where the book value of the asset is nil, the entire proceeds of sale be treated as income.

Specific Donations: These are received for a specific purpose. For example: donation for building; donation for prizes: donation for pavilion etc. These are capital receipts and. It is worthy to note that such donations should be treated as income because if they are taken to income and expenditure account, it will increase income. The increased income may be utilized for any other purpose.

General donations: These may come inform of tithes, pledges, or church offerings that the church members usually pay. These donations are not for any specific purpose and being a recurring income they are to be treated as income and are shown on the income side of income and expenditure account

Endowment fund: It represents donation for a specific purpose. Here, the object of the donor is to provide a source of permanent income to the institution. Thus, it is shown in the liability side of balance sheet. Any income earned during the year in such found is added to it and any expenditure incurred during the year is deducted from it.

Proceeds of Concerts, Lectures and Dramas or Cultural Shows: A concert is a program of musical entertainment. Concerts and lectures of eminent personalities are arranged in aid of charities. Accounts of Non-Trading institutions.Amount in the income side of institutions. Amount collected from such how by the sale of tickets is an income of institution and Amount in the income side of institutions.

Accumulated (Capital) Fund: All entities, profit-seeking on non-profit seeking require money for carrying out their activities. In a business organization such money is called capital while in case of non-profit organizations it is known by various names such as Capital fund or Accumulated fund.

It represents the surplus of assets over outside liabilities of the organization. It is usually made up by special donations; legacies; capitalization of admission fee; life membership fee etc. it is increased (or decreased) by any surplus (or deficit) on the Income and Expenditure account. Some of the lesser known names given to this item are General fund or Surplus account.

\subsection{Differences between Nonprofits and For-Profits Organizations}

The following table highlights some of the key differences between nonprofit organizations and for-profit corporations as opined by William and Keller (2006).

\begin{tabular}{|c|c|c|}
\hline & NONPROFITS & FOR-PROFIT CORPORATIONS \\
\hline Primary mission: & Provide services needed by society & Exam profits for stockholders \\
\hline Secondary mission: & $\begin{array}{l}\text { Ensure that revenues are greater than expenses so that the services } \\
\text { provided can be maintained or expanded }\end{array}$ & Provide services or sell goods \\
\hline U. S. tax status: & Exempt from income taxes if approved by IRS & $\begin{array}{l}\text { Corporations (or their owners) are subject to } \\
\text { income taxes }\end{array}$ \\
\hline \multirow[t]{2}{*}{$\begin{array}{l}\text { Main financial statements required by U.S. } \\
\text { generally accepted accounting principles (US } \\
\text { GAAP) }\end{array}$} & $\begin{array}{l}\text { Statement of financial position } \\
\text { Statement of Activities }\end{array}$ & $\begin{array}{l}\text { Balance sheet } \\
\text { Income statement or statement of operations } \\
\text { Balance sheet }\end{array}$ \\
\hline & Statement of functional Expenses (for some nonprofits) & $\begin{array}{l}\text { Income statement or statement of operations } \\
\text { Statement of Cash Flows }\end{array}$ \\
\hline $\begin{array}{l}\text { Total assets minus total liabilities is reported } \\
\text { as: }\end{array}$ & $\begin{array}{l}\text { Notes to Financial Statements } \\
\text { Net assets }\end{array}$ & $\begin{array}{l}\text { Notes to financial statement } \\
\text { Stockholder equity }\end{array}$ \\
\hline Subparts are reported as: & $\begin{array}{l}\text { Unrestricted, temporarily restricted, and permanently restricted net } \\
\text { assets (all based on the donors' stipulations). }\end{array}$ & $\begin{array}{l}\text { Paid-in capital retained earnings minus } \\
\text { treasure examples of revenues:y stock }\end{array}$ \\
\hline Examples of revenues: & $\begin{array}{l}\text { Donor contributions, membership dues, program fees, fundraising } \\
\text { events, grants, and investment incomer }\end{array}$ & $\begin{array}{l}\text { Sales of merchandise, fees from services } \\
\text { investment income gains } \mathrm{n} \text { investments }\end{array}$ \\
\hline $\begin{array}{l}\text { Nonprofit expenses are reported by these } \\
\text { functions }\end{array}$ & Program, management and general, and fundraising & \\
\hline $\begin{array}{l}\text { Sources of money other than revenues and the } \\
\text { sale of assets }\end{array}$ & Borrow from lenders & $\begin{array}{l}\text { Borrow from lend } \\
\text { Issue shares of stock }\end{array}$ \\
\hline $\begin{array}{l}\text { Additional annual reporting for some larger } \\
\text { organizations }\end{array}$ & internal revenue Service (IRS) form 990 (churches are exempt) & \\
\hline
\end{tabular}

Table 1: Differences between Nonprofits and For-Profits Organizations 


\subsection{Mission, Ownership, Tax-Exempt Status of a nonprofit organization}

Mission and Ownership: According to Wilkinson (1997), while businesses are organized to generate profits, nonprofits are organized to address needs in society. As a result, nonprofits will issue a statement of activities instead of the income statement issued By For-profit businesses. Since Nonprofits do not have owners, is no owners equity and there cannot distributions to owners. Some people mistakenly assume that if any organization is designated as a nonprofit, it cannot legally earn profits. In fact, earning profits (having revenues that exceed expenses) is almost a necessity for a nonprofit if it hopes to withstand such things as:

- Unexpected Expenses

- Uneven Flows Of Revenues

- A Decrease In Revenues

- An Increase In Staffing Needs

- An Increase In The Need For Its Services

- A Purchases Or Replacement Of Needed Equipment

Tax Exempt Status: Nonprofit organizations may apply to the internal revenue Service in order to be exempt from federal income taxes.

A second issue is whether a donor's contribution to a nonprofit organization will qualify as a charitable deduction on the donor's income tax return. For example, churches, schools, and Red Cross chapters are some of the nonprofits that will qualify as tax-exempt and their donors' income tax returns.

However, there are nonprofits that qualify as tax-exempt out their donors' contributions do not qualify as charitable deductions (although they may qualify as business expenses). Examples of these nonprofits include social organizations, chambers of commerce, college fraternities and pororities amateur sports clubs, employee organizations, and more.

\subsection{Challenges faced by non-profit organization}

Those starting nonprofit organizations are found struggling with the following issues as outlined by Zimmerman (1997).

Fund raising: fund is a major concern area for startup non-organization. An organization cannot raise fund till it has the state solicitation registration done. It is quite common for startup non-profits to be without fund until the paper work is completed. To begin with, nonprofit organizations look for internal sources of funding from members, families, friends and other affinity groups

Community support: Garnering community support takes time and a function of how well the organization commits it purpose to the communities. Effective branding exercises are found to be extremely helpful for garnering community support. Getting dedicated volunteers to execute organizations projects is another challenges faced by nonprofit organizations, turn to tap the local resources in the beginning.

Registration and legal paper work: Typically, a nonprofit organization is required to register with the office of secretary of state or internal revenue service's before it can start raising funds for its operations. Fund solicitation registration with the internal revenue service sometimes is very time-consuming.

Book keeping and accounting: accountability is a prime concern area for all the regulators of nonprofit organizations and book keeping is the backbone of disclosure some nonprofit organizations struggle to keep their books and records updated. Organization with no accounting capabilities often outsource this task to a professional accountant.

Compliance with multiple authorities: many nonprofit organizations like churches do have branches or perishes all over the countries with the founder at the head office expecting a report of stewardship. Also, compliance involves sending an annual report to the various designated office like internal revenue service. Compliance increase manifold for an organization that hires employees or if it opts for complex fund raising methods like annuities.

\subsection{Formation And Structure}

According to Owojori (2001). Non-profits can have members but many do not. The profit may also be a trust or association of members. The organization may be controlled by its members who elect the Board of Directors, Boards of governors or Board of Trustees. Non - profit may have a delegate structure to allow for the representation of groups or corporations as members. Alternatively, it may be a non - membership organization and the board of directors may elect its own successors. The two major types of non-profit organization are membership and board - only. A 
membership organization elects the board and has regular meetings and power to amend the by-law. A board - only organization typically has a self - selected board, and a membership whose powers are limited to those deleted to it by the board. A board - only organizations bylaw even state the organization does not have any membership.

\section{Data and Methodology}

The appropriate sample size of the study is determined using YaroYameneformular;

$n=\frac{N}{1+N(e)^{2}}$

Where $\mathrm{n}=$ Sample size

$$
\begin{aligned}
& \mathrm{N}=\text { Population of Interest } \\
& \mathrm{e}=\text { Error Estimate, which is normally } 5 \% \\
& \mathrm{I}=\text { Constant }
\end{aligned}
$$

Since our the population of the study is 100 , our sample size will be;

$$
\begin{aligned}
& \mathrm{n} \quad=\frac{100}{1+100(0.05)^{2}} \\
& =\frac{100}{1+100(0.0025)} \\
& =\frac{100}{1+0.25} \\
& =\frac{100}{1.25} \\
& \mathrm{n} \quad=80
\end{aligned}
$$

Thus, the sample size for this study is 80

Both primary and secondary sources of data collection were used in generating the relevant data for this study. The questionnaire was used to obtain information as a primary source while textbooks, journals, and internet constituted secondary sources of data collection. The questionnaire was designed showing closed-ended questions- strongly agreed, agreed, strongly disagreed and disagreed responses. The questionnaire was administered to members of the Redeem Christian Church of God Abia Province, World Bank Housing Estate, Umuahia, Abia State.

In analyzing the data, the researcher adopted simple descriptive and inferential statistics. Simple descriptive statistics involves the use of tables, frequency and percentage. Objective (i \&iv) were analyzed using descriptive statistics; while

\begin{tabular}{|c|c|c|c|c|c|c|c|}
\hline & & & $\begin{array}{l}\text { Sum of } \\
\text { Squares }\end{array}$ & df & $\begin{array}{c}\text { Mean } \\
\text { Square }\end{array}$ & $\mathrm{F}$ & Sig. \\
\hline \multirow{3}{*}{$\begin{array}{l}\text { Financial } \\
\text { Activities * } \\
\text { Accounting } \\
\text { System }\end{array}$} & Between Groups & (Combined) & 164.915 & 3 & 54.972 & 2.439 & .026 \\
\hline & Within Groups & & 8272.585 & 66 & 125.342 & & \\
\hline & Total & & 8437.500 & 69 & & & \\
\hline
\end{tabular}
objective (ii\& iii) were analyzed using ANOVA. The formulated hypotheses were analyzed using ANOVA.

\section{Analysis and Discussion Of Findings}

\subsection{Testing of Hypotheses}

H0: $\quad$ There is no significant relationship between accounting system and financial activities of the organization Table 2: Section B item 3 was used to test if there is actually no significant relationship between accounting system and financial activities of the organization

ANOVA Table 2

Source: Data Analysis using SPSS Version 20

Reject null hypothesis if $\mathrm{f}-\mathrm{cal}$ is greater than $\mathrm{f}$-tab and reject alternative hypothesis if $\mathrm{f}$-cal less than $\mathrm{f}$-tab at 0.05 level of significance.

The computed or calculated value of F using SPSS version 20 is 2.439 while the tabulated value of F is 2.353 . Since the F-cal> F-tab $(2.439>2.353)$, the formulated null hypothesis which states that there is no significant relationship 
between accounting system and financial activities of the organization is rejected while the alternative hypothesis is accepted.

$\mathbf{H O}_{2}$ : Adoption of accounting system does not enhance accountability and transparency.

Table 3: Section B item 6 was used to test if the adoption of accounting system enhances accountability and transparency.

ANOVA Table 3

\begin{tabular}{|c|c|c|c|c|c|c|c|}
\hline & & & $\begin{array}{l}\text { Sum of } \\
\text { Squares }\end{array}$ & $\overline{\mathrm{df}}$ & $\begin{array}{c}\text { Mean } \\
\text { Square }\end{array}$ & $\bar{F}$ & Sig. \\
\hline \multirow{3}{*}{$\begin{array}{l}\text { Accounting and } \\
\text { Transparency * } \\
\text { Accounting } \\
\text { System }\end{array}$} & Between Groups & \multirow[t]{3}{*}{ (Combined) } & 76.420 & 3 & \multirow{3}{*}{$\begin{array}{l}25.473 \\
64.562\end{array}$} & \multirow[t]{3}{*}{2.569} & \multirow[t]{3}{*}{.035} \\
\hline & Within Groups & & 4261.080 & 66 & & & \\
\hline & Total & & 4337.500 & 69 & & & \\
\hline
\end{tabular}

Source: Data Analysis using SPSS Version 20

\section{Decision Rule:}

Reject null hypothesis if $\mathrm{f}-\mathrm{cal}$ is greater than $\mathrm{f}$-tab and reject alternative hypothesis if $\mathrm{f}$-cal less than $\mathrm{f}$-tab at 0.05 level of significance.

The computed or calculated value of F using SPSS version 20 is 2.569 while the tabulated value of F is 2.353 . Since the F-cal> F-tab (2.569> 2.353), the formulated null hypothesis which states that the adoption of accounting system does not enhance accountability and transparency is rejected while the alternative is accepted.

\subsection{Discussion of Findings}

The result of the analysis conducted above using SPSS version 20, revealed the crucial role accounting system plays in assisting organization either profit oriented or not to achieve their goals and objective. The computed F-values of the above two tables which are greater the tabulated revealed that the use of accounting system ensures the reliability of accounting records, keeps managers and other top personnel in the organization abreast with current financial activities, reveals the financial stability and credit worthiness of organizations and gives top members of the church like the senior pastor, financial secretary and treasurer's easy access to financial records and information of the church.

\section{Conclusion and Recommendations}

The research focused on appraising accounting system in nonprofit making organization, with specific interest on Redeemed Christian Church of God, World Bank Province, Umuahia, Abia State. The researcher distributed a structured questionnaire to sample members of the church in order to generate relevant responses from the selected respondents on the role of accounting in nonprofit making organization. The data generated from the respondents were analyzed using simple descriptive statistics and the formulated hypotheses tested using the inferential statistics Analysis of Variance with the aid of statistical package (SPSS version 20). The results of the findings are summarized below:

- There is a significant relationship between accounting system and financial activities of the organization

- $\quad$ The adoption of accounting system does enhance the accountability and transparency of financial records and activities of the Church.

- The attitude of senior officials of the Church towards accounting system is negative.

- The use of accounting system has a strong effect on the financial activities of the organization.

- The use of accounting system shows the financial records, actual income and expenditure of the organization.

Nonprofit organization in recent time has witnessed remarkable achievements in the areas of accurate record keeping, easy accessibility to information on the financial activities of the organization, a drastic reduction in the appropriation and high embezzlement of funds by a top official. These notable achievements are as a result of the adoption of accounting system in generating financial information needed to aid decision-making process on the financial activities of the organization.

The researcher, based on the result of the analysis concluded that; the use of accounting system has a strong effect on the financial activities of the organization, accounting system enhances reliability and accuracy of financial records, 
effective accounting system has a significant impact on its financial reporting, the use of accounting system reveals the financial records and expenditure of the organization.

The result of the empirical analysis conducted propelled the researcher to make the following recommendations: Business organizations either profit oriented or not should intensify the use of accounting system within various units of the organization since it ensures the efficiency of financial activities.

- Accounting system should be adopted by nonprofit organization to enhance the accountability and transparency of financial records and activities of organizations.

- Senior officials of the Church should develop a positive attitude towards accounting system owing to its notable contribution to the growth and development of the Church.

- Accounting system should be used by organizations in record keeping and auditing of financial activities since it shows the financial records, actual income and expenditure of the organization.

- Adequate training should be given to senior pastors, treasurers and financial secretary of the church in order to increase their performance and effective use of established accounting system in the church.

\section{References}

- Alsharayri, M. (2013). Evaluating the performance of Accounting System in Jordanian Private Hospitals. Journal of Social Sciences 8 (1), 74-78.

- Barth, M. E., W.H. Beaver and W. R. Landsman (2001). The Relevance of Value Relevance Literature for Financial Accounting Standard Setter: Another View. Journal of Accounting and Economics, 31(1-77 - 104.

- Beaver, W. H., and J. Demski, (2003). The Nature of Financial Accounting objectives: a summary and synthesis. Journal of Accounting Research, 170-182.

- Boockholdt, J. (1999). Accounting Systems Transaction Processing and Control. The Mac- Graw-Hill companies, 5, 433-444.

- Chang, Y. W. (2001). Contingency factors and Accounting System in Nonprofit Organization: design in Jordanian companies. Journal of Accounting System, 8, 1-16.

- Choe, J. M. (1996). The Relationships among Performance of Accounting Systems, influence factors, and evolution level of information systems, Journal of accounting Systems in nonprofit organization in Nigeria, 12(4), 215-239.

- Huber, G. (1990). A Theory of the Effects of Advanced information Technologies on Organizational Design, Intelligence and Decision-Making.

- Meyer, C. (2007). Shareholder Value Accounting - the value relevance of financial statement data and the determinants of accounting method choices.

- Nicolaou, A. L. (2000). A contingency Model of Perceived Effectiveness in Accounting Systems in Organizational Coordination and Control Effects. International Journal of Accounting Systems in nonprofit organization 1(2), 91-105.

- Ologunde, A. O., D.O. Elumilade and T.O. Asaolu (2006). Stock Market Capitalization and Interest Rate in Nigeria: A Time Series Analysis, International Research Journal of Finance and Economics, 4(1).

- Owojori, A. A. (2001). International Accounting. Ado-Ekiti: Kaycee Publishers.

- Quinn, R. and Rohrbaugh, J. (2005). A Spatial Model of Effectiveness Criteria: Towards a competing Values Approach to Organizational Analysis. Management Science, 29, 77-91.

- $\quad$ Romney et al., (2003). Accounting Systems on nonprofit organization (9th ed.). New Jersey: Pearson Prentice Hall.

- Wilkinson, J. W. (1993). Accounting Systems on non profit making organization: Essential Concepts and Applications. ( $2^{\text {nd }}$ ed.). New York: John Wiley \& Sons Inc.

- Zimmerman, J. (1997). Accounting for Decision making and control. Boston: Irwin/McGraw Hill. 